\title{
Preparation of Quantum Dot Bioconjugates as Fluorescence Probe for Targeting and Visualization of Cells
}

\author{
Hücrelerin Hedeflenmesi ve Görüntülenmesi için Floresans Prob \\ Olarak Kuantum Nokta Biyokonjugatlarının Hazırlanması
}

\author{
Research Article \\ Dilek Odaci Demirkol and Suna Timur* \\ Ege University, Faculty of Science, Biochemistry Department, Bornova, Izmir Turkey.
}

\section{A B S T R AC T}

$\mathrm{H}$ ere, the bioconjugation and application of water-soluble quantum dots (QDs) for targeted cellular imaging were investigated. Human anti-c-ErbB2 antibodies were bound to QDs for the targeting of these nanostructures towards the cancer cells. QDs and anti-c-ErbB2/QD bioconjugates were characterized by fluorescence and UV-Vis spectroscopy and hydrodynamic sizing. The effect of QDs and anti-c-ErbB2/QD bioconjugates on cell viability was evaluated using an MTT assay. To observe targeting efficiency of anti-cErbB2/QD bioconjugates, fluorescence microscopy and was performed. Higher cell affinities were obtained by anti-c-ErbB2-conjugated QDs which is an evidence that these are well-suited for targeting and imaging of cells.

\section{Key Words}

Quantum dots, bioconjugation, anti-c-ErbB2, cell targeting.

\section{öz}

\begin{abstract}
urada, hedeflenmiş hücresel görüntüleme için suda çözünür kuantum noktaların (QD) biyokonjugasyonu ve uygulamaları gerçekleştirilmiştir. Kanser hücrelerine nanoyapıların hedeflenmesi için anti-c-ErbB2 antikoru QD'lara bağlanmıştır. QD'lar ve anti-c-ErbB2/QD biyokonjugatları floresans/UV-Görünür bölge spektroskopisi ve hidrodinamik boyut ölçümleri ile karakterize edilmiştir. Hücre canlılığına QD'lar ve antic-ErbB2/QD biyokonjugatlarının etkisi MTT denemeleri kullanılarak gerçekleştirilmiştir. Anti-c-ErbB2/QD biyokonjugatlarının hedefleme etkinliğini gözlemlemek için, floresans mikroskopi kullanılmıştır. Hücreleri görüntüleme ve iyi gerçekleştirilmiş hedeflemenin ispatı olarak anti-c-ErbB2 konjuge edilen QD'lar ile daha yüksek hücre afiniteleri elde edilmiştir.
\end{abstract}

\section{Anahtar Kelimeler}

Kuantum noktalar, biyokonjugasyon, anti-c-ErbB2, hücre hedefleme.

Article History: Received: Apr 7, 2017; Revised: Jun 10, 2017; Accepted: Oct 20, 2017; Available Online: Dec 25, 2017. DOI: 10.15671/HJBC.2018.183

Correspondence to: S. Timur, Ege University, Faculty of Science, Biochemistry Department, Bornova, Izmir, Turkey 


\section{INTRODUCTION}

D evelopment and design of new fluorescence probes for targeting and imaging have great attention in biomedical technologies and biomedicine. Scientists focused on developments of targeting and bioimaging probes in improved properties [1-3]. Fluorophores, which are used in visualization of cells, can be divided some main groups such as organic dyes, conjugated polymers and inorganic-organic nanostructures [2-7].

Semiconducting nanoparticles (quantum dots: QDs) are [8,9] new type of markers which are applied to screen biostructures using optical sensing technologies. QDs have characteristic properties in comparison to fluorescence dyes, such as possibility to synthesize in different excitation/emission wavelengths, long fluorescence life time, resistance to metabolic degradation and high quantum yields [10-12]. Furthermore, QDs are colloids with similar size to large proteins, dispersed in an aqueous solvent and covered with organic structures to stabilize their dimensions [13]. Also the surfaces of QDs can be modified various functional groups such as amine and carboxyl [2,3]. The solubility of QDs in aqueous media are important for their applications on biological samples. Also the solubility of QDs affect bioconjugation conditions with ligands. Several cell-targeting ligands have been reported to modify QDs in previous studies. Bharali et al. synthesized hidropholic InP Quantum Dots and modified with folic acid. The delivery of bioconjugates into folate-receptor-positive cell lines was demonstrated and receptor-mediated delivery was proved [14]. In another study, dendrimermodified quantum dots were synthesized and were conjugated with Arginine-GlycineAspartic Acid (RGD) by Li et al. [15]. The designed bioconjugates injected into nude mice loaded with melanoma (A375) tumor xenografts via tail vessels. Furthermore, HER2 monoclonal antibody conjugated RNase A-associated CdTe quantum dot cluster (HER2-RQDs) nanoprobes was formed and applied for targeted imaging and therapy of gastric cancer cells (MGC803) [16]. In our previous studies, QDs were covered with amine-terminated polyamidoamine (PAMAM) dendrimer and HER2 receptor-mediated targeting efficiency of antibody labelled PAMAM/QD conjugates was proved [2]. In another study, synthesis, characterization, bioconjugation with anti-HER2, and application of water-soluble thioglycolic acid TGA-capped CdTe/ CdS quantum dots (TGA-QDs) were carried out [3].

Human epidermal growth factor (EGF) receptor 2 (ErbB2) has been well known important cell surface protein for breast cancer. c-erbB2 is overexpressed in cancer cells especially breast cancer. Anti-c-erbB2 was used to detect the wellknown breast cancer biomarker c-erbB2 in previous studies $[17,18]$. In this study, anti-c-ErbB2 antibody and carboxyl-QDs were used to form anti-c-ErbB2/ QD bioconjugates for targeting of cancer cells. First, the optimization of loading amount of $A b$ to QDs were carried out. Then, the effect of bioconjugates on cell viability was tested. Finally, fluorescence imaging of cells using anti-c-ErbB2/QDs conjugates was investigated.

\section{MATERIALS and METHODS}

\section{Materials}

Rabbit monoclonal antibody to human c-ErbB2 protein was purchased from Diagnostic Biosystems. (3-(4,5-Dimethylthiazol2-yl)-2,5-diphenyltetrazolium bromide (MTT), 2-(N-morpholino)ethanesulfonic acid (MES), 1-ethyl-3-(3-dimethylaminopropyl) carbodiimide (EDC), N-hydroxysuccinimide (NHS) were purchased from Sigma. Phosphate buffer solution was prepared at the following composition: $8.0 \mathrm{~g} / \mathrm{L}$ $\mathrm{NaCl}, 0.2 \mathrm{~g} / \mathrm{L} \mathrm{KCl}, 1.44 \mathrm{~g} / \mathrm{L} \mathrm{Na}_{2} \mathrm{HPO}_{4}$ and $0.24 \mathrm{~g} / \mathrm{L}$ $\mathrm{KH}_{2} \mathrm{PO}_{4}$. All other chemicals were analytical grade.

\section{Instrumentation}

Eppendorf thermomixer comfort (2.0 mL) was used to keep temperature at $25^{\circ} \mathrm{C}$ during conjugation of antibody with QDs. Thermo electron corporation HERA cell $240 \mathrm{CO}_{2}$ incubator was used for cultivation of cancer cells. Emission and absorbance spectrum of QDs were recorded with NanoDrop 3300 Fluorospectometer and NanoDrop ND 1000 spectrophotometer, respectively. Biorad Model 680 microplate reader was used to read absorbance in MTT assay. Average particle size and size distribution of the QDs/anti-c-ErbB2 bioconjugates were measured using Dynamic Light Scattering (DLS, Malvern Instrument, U.K). The QDs and anti-c-ErbB2/D bioconjugates were diluted with PBS before measurements. 


\section{Bioconjugation Reactions of QDs and Anti-c- ErbB2}

The synthesis of thioglycolic acid modified carboxyl-QDs and bioconjugates of anti-cErbB2 with QDs were carried out according the literature [1-3]. Briefly, $0.2 \mathrm{~mL}$ of $\mathrm{QD}$ solutions were mixed with $0.025 \mathrm{~mL}$ of EDC $(0.2 \mathrm{M}$ in MES buffer, $25 \mathrm{mM} \mathrm{pH}, 6.0), 0.025 \mathrm{~mL}$ of NHS (0.05 $M$ in MES buffer, $25 \mathrm{mM} \mathrm{pH:6.0)} \mathrm{and} \mathrm{carboxyl}$ groups of QDs were activated for $15 \mathrm{~min}$ at room temperature. Then anti-c-ErbB2 antibody ( $25 \mu \mathrm{g} /$ $\mathrm{mL}$ ) was added and reaction was completed in 2 $\mathrm{h}$ at room temperature. Finally, the bioconjugates were purified using PALL corporation, VWT nanosep 300K omega membrane filter (MWCO: $300 \mathrm{KD}$ ) and washed with PBS for 4 times.

\section{Cell Culture}

MCF-7 (breast cancer), NIH-3T3 (mouse fibroblast), Caco-2 (colon cancer), A-549 (human lung cancer) and HEP-G2 (liver cancer) cell lines were provided from German Collection of Microorganisms and Cell Cultures (DSMZ). MCF-7 cells were cultivated in Minimum Eagle's Medium (MEM) media containing 10\% Fetal Calf Serum (FCS), $1.0 \%$ Na-pyruvate, $1.0 \%$ L-glutamine, $10 \mu \mathrm{g} / \mathrm{mL}$ insulin, 1.0\% non-essential amino acids and 1.0\% penicillin/streptomycin (P/S). NIH-3T3 cells were cultivated in Dulbecco's Modified Eagle's Medium (DMEM) containing 10\% Newborn Calf Serum (NCS) and $1.0 \% \mathrm{P} / \mathrm{S}$. Caco-2 cells were cultivated in MEM containing $20 \% \mathrm{FCS}$ and $1.0 \% \mathrm{P} / \mathrm{S}$. A-549 and HEP-G2 cells were incubated in DMEM containing $10 \% \mathrm{FCS}$ and $1.0 \% \mathrm{P} / \mathrm{S}$. All cells were cultivated in medium at $37^{\circ} \mathrm{C}$ in humidified environment of $5.0 \% \mathrm{CO}_{2}$.

\section{In vitro Cytotoxicity}

( 3- (4,5-Dimethylthiazol-2-yl)-2,5diphenyltetrazolium bromide (MTT) reduction test were used to determine cytotoxicity of QDs and anti-c-ErbB2/QD bioconjugates. Cells were seeded out in 96 -well-tissue plates. The cultivation took three days at $37^{\circ} \mathrm{C}, 5.0 \% \mathrm{CO}_{2}$ and $100 \%$ air humidity. After this cultivation time the wells were confluent populated. The medium was removed and the cells were incubated with QDs samples solved in medium. Then the samples were carefully removed. This removal has to be very exhaustive. Otherwise reducing medium or sample ingredients are able to react with MTT solution and cause false-positive results. 110 $\mu \mathrm{L}$ freshly prepared MTT solution (10\%) in cell corresponding medium were added per well. The cells were incubated at $37^{\circ} \mathrm{C}, 5.0 \% \mathrm{CO}_{2}, 100 \%$ air humidity for $4 \mathrm{~h}$. While this incubation time the formazan complex was produced inside the cells. To release the purple colored salt $100 \mu \mathrm{L}$ SDS solution in $1.0 \mathrm{M} \mathrm{HCl}(10 \%)$ were added per well and the plates are incubated at $37^{\circ} \mathrm{C}, 5.0 \% \mathrm{CO}_{2}$, $100 \%$ air humidity for $24 \mathrm{~h}$. Finally, the plates were red out in a plate reader (spectrophotometer). A decrease of living cell amount causes a decrease of metabolic activity. This activity is correlated directly with the amount of produced purple formazan (at $570 \mathrm{~nm}$ ).

\section{Cell Imaging}

Each cells (MCF-7: $8000 \mathrm{cfu} / \mathrm{mL}, \mathrm{NIH}-3 \mathrm{~T} 3: 10000$ $\mathrm{cfu} / \mathrm{mL}$, Caco-2: $8000 \mathrm{cfu} / \mathrm{mL}, \mathrm{A}-549: 8000 \mathrm{cfu} /$ $\mathrm{mL}$ and HEP-G2: $10000 \mathrm{cfu} / \mathrm{mL}$ ) were cultivated in 96-well plate with $5.0 \% \mathrm{CO}_{2}$ in their respective medium at $37^{\circ} \mathrm{C}$ as described before. After $72 \mathrm{~h}$ cultivation, adherent cells were washed twice with PBS. And $0.1 \mathrm{~mL}$ of QDs, diluted with PBS, was added into the wells. The cells were allowed to be incubated with the QDs for $4 \mathrm{~h}$ and were washed 2 times with PBS after incubation. The cell imaging studies were carried out using Olympus IX50 fluorescence microscope with 10x and 40x magnifications. The preparation and applications of anti-c-ErbB2/QD bioconjugates were depicted in Sheme 1.

\section{RESULTS and DISCUSSION}

\section{Characterization of Anti-cErbB2/QDs Bioconjugates}

UV-VIS Spectrometer and fluorescence spectrophotometer were used for characterization of optical properties of QDs. Figure 1 shows the UV-VIS absorption spectrum of QDs in aqueous solution together with the emission spectra after excitation at $470 \mathrm{~nm}$. QDs exhibit visible emission at 550 nm.

The fluorescence intensity of emission was found to decrease with the increase in antibody amount. These results are consistent with the previous studies. Figure 2 shows the 


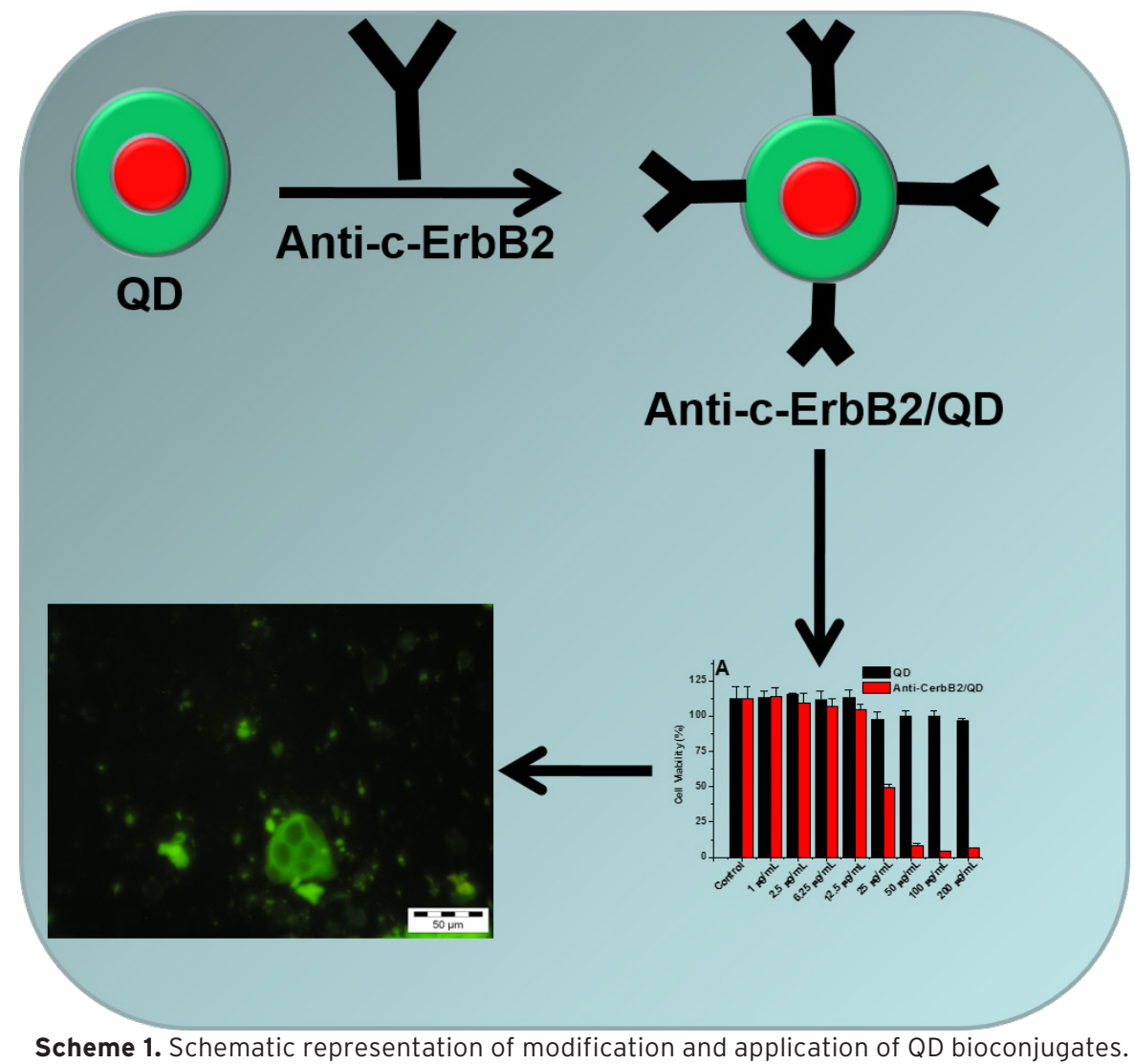

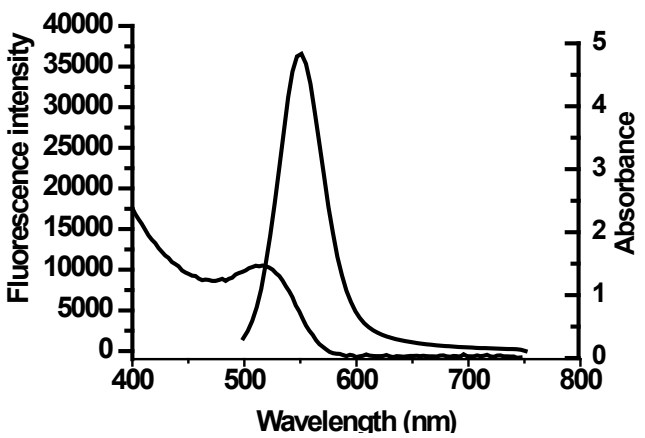

Figure 1. Absorption (A) and emission (B) spectra after excitation at $470 \mathrm{~nm}$ of QDs dispersed in PBS.

emission spectra of QDs after loading of varying concentration of antibody. Addition of targeting ligands to QDs results in the change of biological or chemical and physical properties of QDs. When stoichiometric ratio of QDs to capping agent such as folic acid or antibody decreases the PL intensity decreases $[19,20]$. Manzoor et. al explained two ways to occur this decrease. First, the light to reaching to QDs was filtered out by the surface conjugated capping agent due to the absorption of excited light. Secondly, the non-radiative energy transfer and/or hot electron exchange can be carried out between QDs and capping agent [19]. After consideration of these results, $28.5 \mu \mathrm{g}$ anti-c-ErbB2 antibody/mg QD was used for furthermore experiments to achieve both cancer targeting and high signals.

To investigate diameter effect of antibody amount, three different concentrations of anti-cErbB2 was loaded to modify QDs. Figure 3 depicts the DLS results of bioconjugates. The hydrodynamic diameters of QDs, 11, 28.5 and $62 \mathrm{mg}$ anti-cErbB2/mg QD loaded conjugates were 10.90 \pm 1.13 , $30.44 \pm 3.15,50.75$ and $58.77 \mathrm{~nm}$ (n: 3), respectively.

In the MTT assay, cells were grown in corresponding medium for $72 \mathrm{~h}$. Then it was

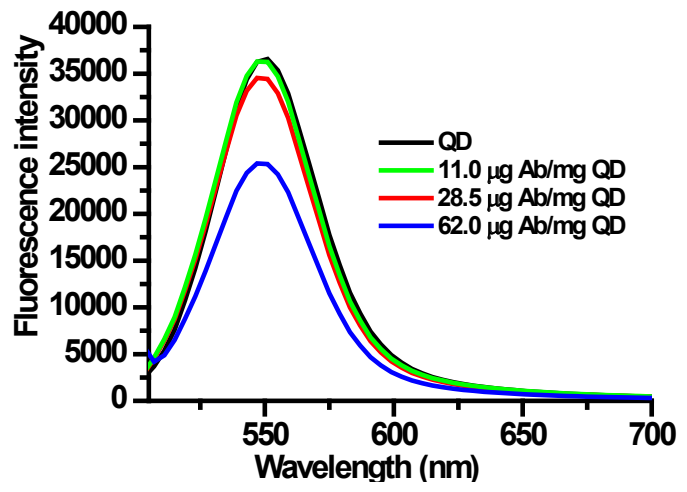

Figure 2. Effect of antibody amount on the fluorescence intensity of QDs. 


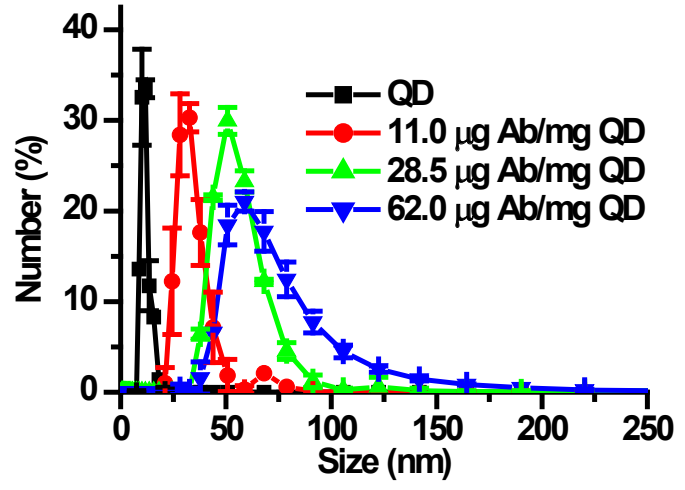

Figure 3. DLS of QD and anti-c-ErbB2/QD bioconjugates.
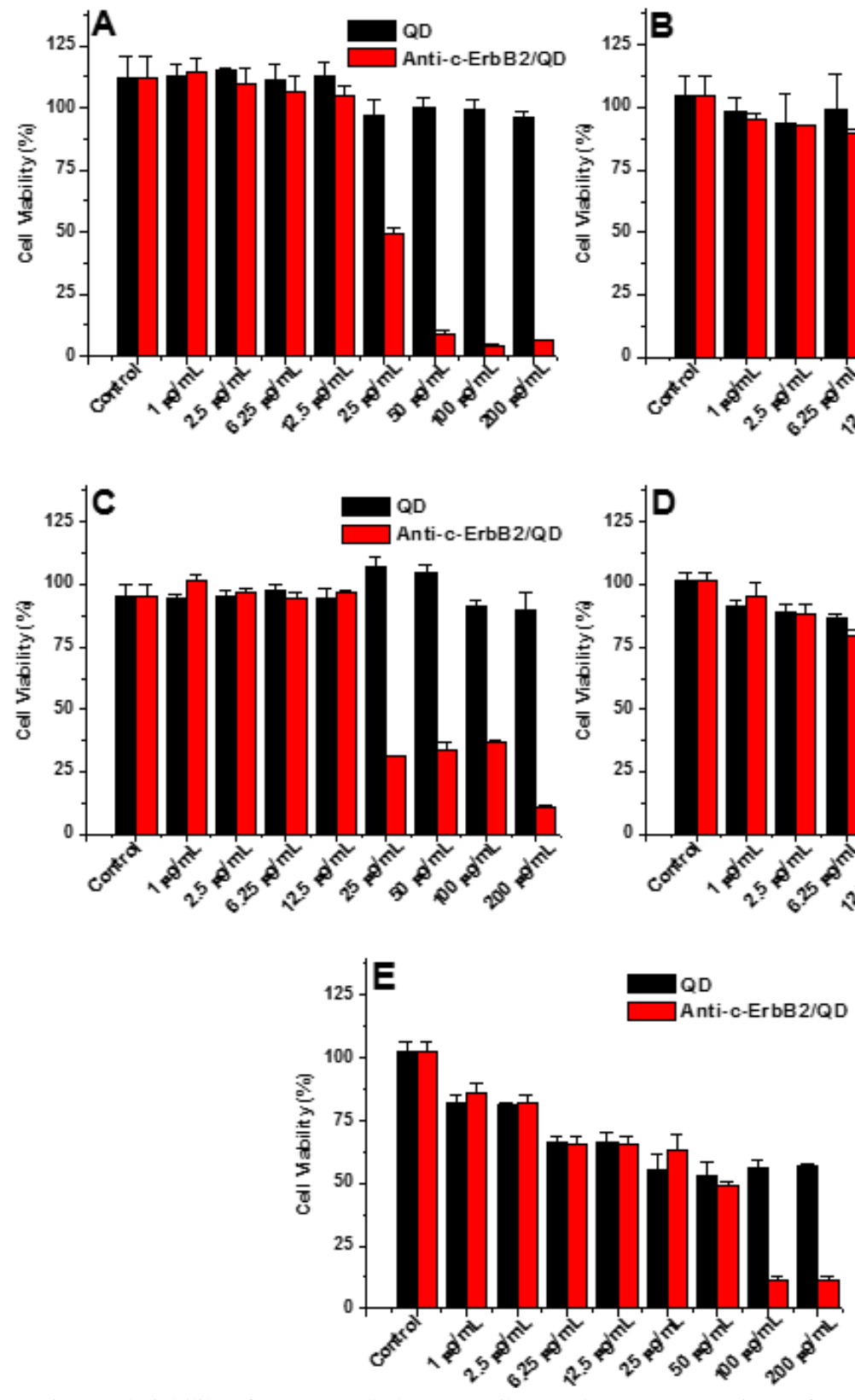

Figure 4. In vitro cell viability of cancer cells treated with varying concentrations of QDs and anti-c-ErbB2/QD conjugates for 4 h (A: HEP-G2; B: MCF-7; C: A549; D: Caco-2; E: NIH-3T3). bioconjugates at a concentration ranging from 0 to $200 \mu \mathrm{g} / \mathrm{mL}$ was added and cells were incubated in $\mathrm{CO}_{2}$ incubator for $4 \mathrm{~h}$. As shown in Figure 4, the cell viability was decreased with increasing $Q D$ concentrations. NIH-3T3 was not resistant to 200 $\mu \mathrm{g} / \mathrm{mL}$ of QDs unlike HEP-G2, A549, MCF-7 and Caco-2 cells. After addition of the biomolecule to structure, the concentration of QD affected all cell lines. Cells kept their viability up to the $12.5 \mu \mathrm{g} / \mathrm{mL}$ of QD. The results were not surprising, because decrease of anionic groups on the surface of QDs
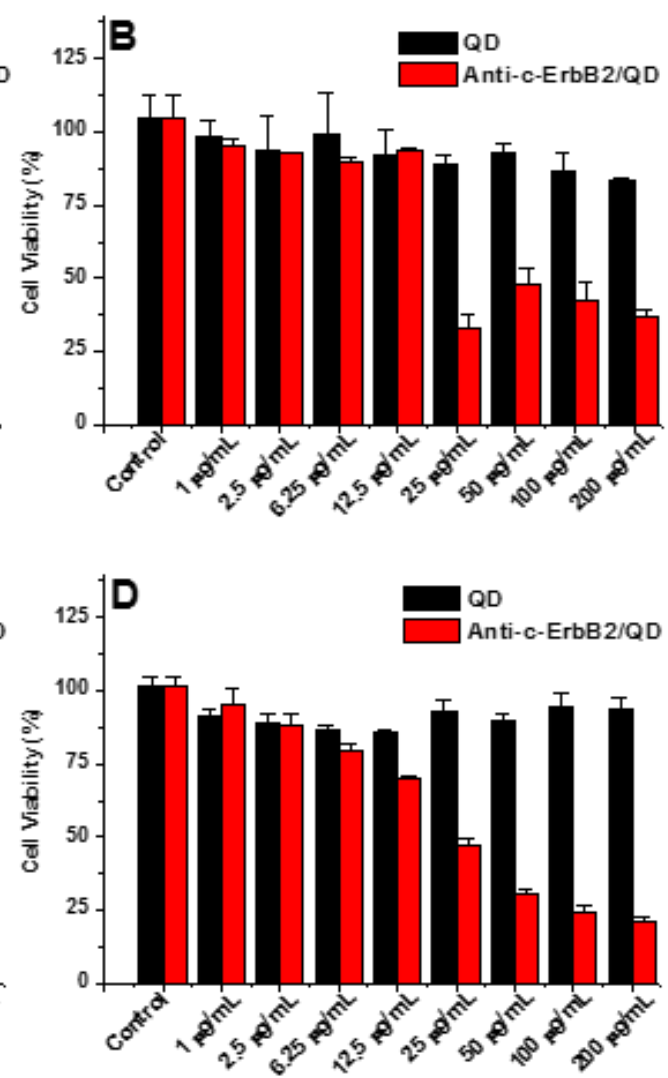

removed and medium containing QDs and 


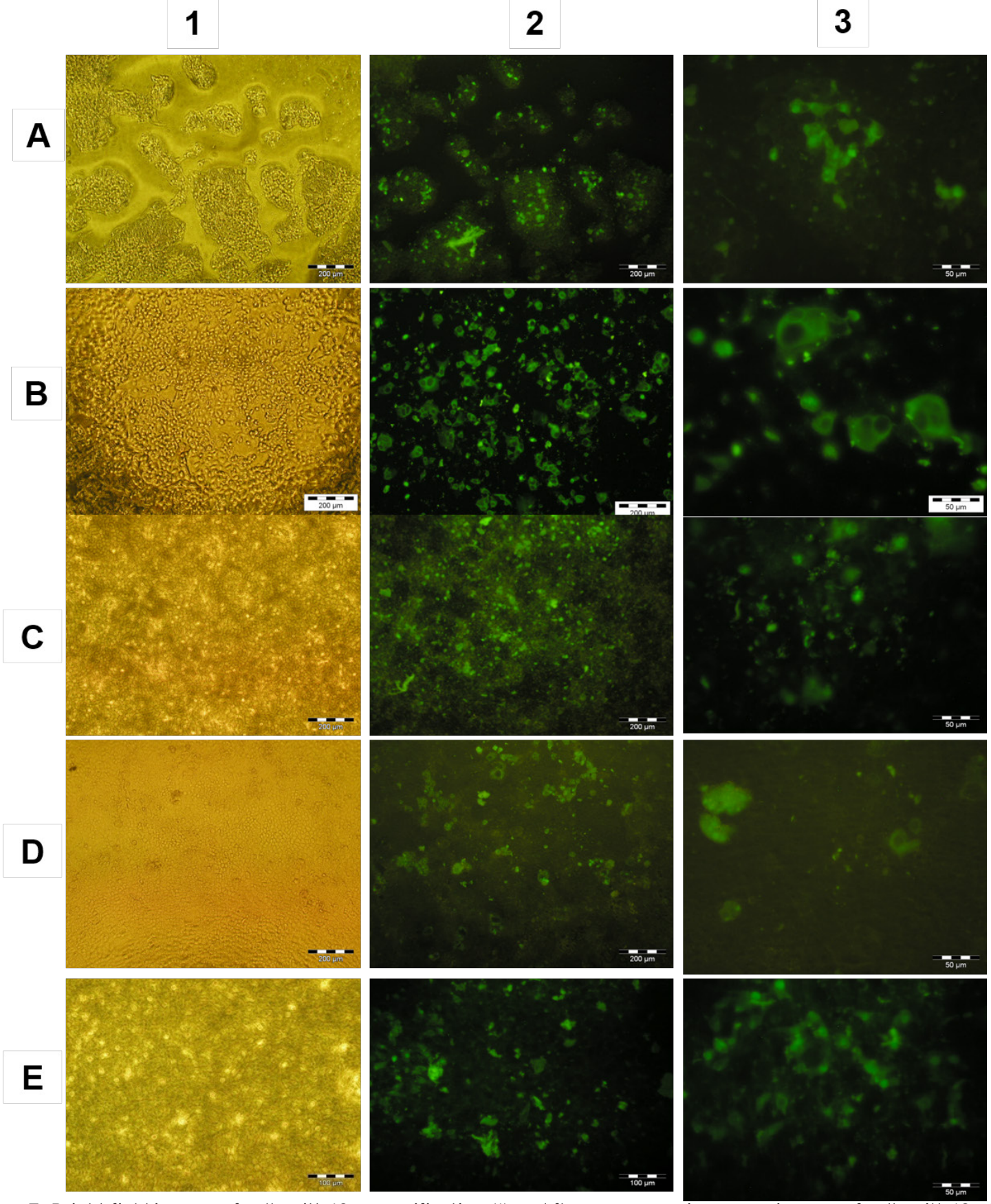

Figure 5. Bright field images of cells with 10x magnification (1) and fluorescence microscopy images of cells with 10x (2) and 40x (3) magnification (cells were treated with QD-anti-c-ErbB2 bioconjugates for 4 h; (A): HEP-G2; (B): MCF-7; (C): A549; (D): Caco-2; E: NIH-3T3).

increases the cytotoxicity [20].

Fluorescence microscopy of anti-c-ErbB2/QD was performed after incubating bioconjugates with A549, MCF-7, HEP-G2, Caco-2 and NIH$3 T 3$ cells for $4 \mathrm{~h}$ at $37 \mathrm{C}$. After modification of the QD surface with antibodies, cellular uptake through endocytosis was carried out [3]. Microscopy images of cells were presented in Figure 5.
Anti-c-ErbB2/QD nonspecifically bound to healthy cells (NIH-3T3 as a model in this assay), but the fluorescence signals and the visualization of cells were much lower than those in A549 cells.

\section{CONCLUSIONS}

The QDs and anti-c-ErbB2/QD bioconjugates were synthesized and applied to image cancer cells. For 
this aim, anti-c-ErbB2 was bound to QDs, including carboxyl groups on their surface, via EDC/ NHS coupling reaction. The formed anti-c-ErbB2/ QD bioconjugates were characterized optically and applied to image cancer cells. The effect of anti-c-ErbB2/QD bioconjugates on cell viability was tested by MTT assay. Taken together, these results suggest that anti-c-ErbB2/QD can be used as fluorescent probes for cellular imaging of cancer cells and in vivo imaging applications, such as biomarker detection.

\section{ACKNOWLEDGEMENTS}

Dr. Dilek Odaci Demirkol thanks to Federation of the Societies of Biochemistry and Molecular Biology (FEBS) for short-term fellowship. Ege University Research Funds (project number; 2012FEN032) are acknowledged for the financial support.

\section{References}

1. D. Odaci Demirkol, S. Timur, A sandwich-type assay based on quantum dot/aptamer bioconjugates for analysis of $E$. coli $0157: H 7$ in microtiter plate format Int. J. Polym. Mater., 65 (2016) 85-90.

2. M. Akin, R. Bongartz, J.G. Walter, D. Odaci Demirkol, F. Stahl, S. Timur, T. Scheper,PAMAM-functionalized water soluble quantum dots for cancer cell targeting, J. Mater. Chem. B, 22 (2012) 11529-11536.

3. D. Ag, L. Eral Dogan, R. Bongartz, M. Seleci, J.G. Walter, D. Odaci Demirkol, F. Stahl, S. Ozcelik, S. Timur, T. Scheper, Biofunctional quantum dots as fluorescence probe for cell specific targeting, Coll. Surf. B, 114 (2014) 96-103.

4. M. Kesik, B. Demir, F.B. Barlas, C. Geyik, S.C. Cevher, D. Odaci Demirkol, S. Timur, A. Cirpan, L. Toppare, Multi-functional fluorescent scaffolds as a multi-color probe: Design and application in targeted cell imaging, RSC Adv., 5 (2015) 83361-83367.

5. D. Goen Colak, I. Cianga, D. Odaci Demirkol, O. Kozgus, I. Medine, S. Sakarya, P. Unak, S. Timur, Y. Yagci, The synthesis and targeting of PPP-type copolymers to breast cancer cells: multifunctional platforms for imaging and diagnosis, J. Mater. Chem. B, 22 (2012) 9293-9300.

6. C. Geyik, E. Guler, Z.P. Gumus, F.B. Barlas, H. Akbulut, D. Odaci Demirkol, S. Timur, Y. Yagci, Bioconjugation and applications of amino functional fluorescence polymers, Macromol. Biosci., 17 (2017) 1600232.

7. E. Guler, H. Akbulut, C. Geyik, T. Yilmaz, Z.P. Gumus, F.B. Barlas, R.E. Ahan, D. Odaci Demirkol, S. Yamada, T. Endo, S. Timur, Y. Yagci, Complex structured fluorescent polythiophene graft copolymer as a versatile tool for imaging, targeted delivery of paclitaxel, and radiotherapy, Biomacromolecules, 17 (2016) 2399-2408.
8. M. Geszke-Moritz, M. Moritz, Quantum dots as versatile probes in medical sciences: Synthesis, modification and properties, Mat. Sci. Eng. C- Mater., 33 (2013) 1008-1021.

9. S.J. Rosenthal, J.C. Chang, O. Kovtun, J.R. McBride, I.D. Tomlinson, Biocompatible quantum dots for biological applications, Chem. Biol., 18 (2011) 10-24.

10. Y. Ghasemi, P. Peymani, S. Afifi, Quantum dot: magic nanoparticle for imaging, detection and targeting, Acta Biomed., 80 (2009) 156-165.

11. T. R. Pisanic, Y. Zhang, T. H. Wang, Quantum dots in diagnostics and detection: principles and paradigms, Analyst, 139 (2014) 2968-2981.

12. C. M. Tyrakowski, P.T. Snee, A primer on the synthesis, water-solubilization, and functionalization of quantum dots, their use as biological sensing agents, and present status, Phys. Chem. Chem. Phys., 16 (2014) 837-855.

13. A.M. Smith, S. Dave, S. Nie, L. True, X. Gao, Multicolor quantum dots for molecular diagnostics of cancer, Expert Rev. Mol. Diagn., 6 (2006) 231-244.

14. D.J. Bharali, D.W. Lucey, H. Jayakumar, H.E. Pudavar, P.N. Prasad, Folate-receptor-mediated delivery of InP quantum dots for bioimaging using confocal and twophoton microscopy, J. Am. Chem. Soc., 127 (2005) 11364-11371.

15. Z. Li, P. Huang, J. Lin, R. He, B. Liu, X. Zhang, S. Yang, P. $\mathrm{Xi}, \mathrm{X}$. Zhang, Q. Ren, D. Cui, Arginine-glycine-aspartic acid-conjugated dendrimer-modified quantum dots for targeting and imaging melanoma, J. Nanosci. Nanotechno., 10 (2010) 1-9.

16. J. Ruan, H. Song, Q. Qian, C. Li, K. Wang, C. Bao, D. Cui, HER2 monoclonal antibody conjugated RNase-Aassociated CdTe quantum dots for targeted imaging and therapy of gastric cancer, Biomaterials, 33 (2012) 7093-7102.

17. B. Seven, M. Bourourou, K. Elouarzaki, J.F. Constant, C. Gondran, M. Holzinger,S. Cosnier, S. Timur, Impedimetric biosensor for cancer cell detection, Electrochem. Commun., 37 (2013) 36-39.

18. K.W. Kim, J. Song, J.S. Kee, Q. Liu, G.Q. Lo, M.K. Park, Label-free biosensor based on an electrical tracing-assisted silicon mirroring resonator with a low-cost broad band source, Biosens. Bioelectron., 46 (2013) 15-21.

19. K. Manzoor, S. Johny, D. Thomas, S. Setua, D. Menon, S. Nair, Bio-conjugated luminescent quantum dots of doped ZnS: a cyto-friendly system for targeted cancer imaging, Nanotechnology, 20 (2009) 65-102.

20. M. Geszke, M. Murias, L. Balan, G. Medjahdi, J. Korczynski, M. Moritz, J. Lulek, R. Schneider, Folic acid-conjugated core/shell ZnS:Mn/ZnS quantum dots as targeted probes for two photon fluorescence imaging of cancer cells, Acta Biomater., 7 (2010) 1327-1338. 
